\title{
The Public-Private-Partnership and Rural Development
}

\section{in Taiwan}

\author{
Kun-Jung Liao \\ (Director of Public Policy and Management Center, Department of Political \\ Science, National Chung Cheng University) \\ Shih- Kai Lin* \\ (Research Assistant of Public Policy and Management Center, Department \\ of Political Science, National Chung Cheng University)
}

\begin{abstract}
This paper discusses a significant public-private partnership (PPP) formed by the government and Taiwanese Farmer Associations. Particularly, it will investigate a pattern of the PPP that has successfully promoted rural development and agricultural modernization in Taiwan since 1950s. Taiwanese Farmer Associations (hereafter TFAs), similar to agricultural cooperatives in South Korea and Japan, have played a policy agent in fostering rural development in this island state since 1950s. TFA's performance inherently came from Japanese Cooperatives before World War II. The Performances of those farmer organizations are combinations of economic, social, and educational synergies. The rural development experiences in Taiwan demonstrate that success of rural modernization is carried out by a special public-private partnership (PPP).

First, this paper discusses formation and development of farmer cooperative organizations in East Asian societies and compare the similarities and differences of practice of those organizations and their relations to the governments among Taiwan, South Korea, and Japan. Secondly, this paper examines collaborative mold and process in which both the government and Taiwan Farmer Associations have been extensively involved. A specific cooperative apparatus between the government and TFA functioning and operating as a perfect PPP has been formed under administrative guidance of the state. Thirdly, this paper looks at input and various supports in financial and policy perspective by the public sector. Fourthly, the paper discusses legal framework, administrative apparatus, and governance pattern for TFA. Fifthly, the paper discuses that a specific PPP successfully involving in rural modernization in Taiwan is significantly derived from the state' guidance that properly regulates a
\end{abstract}

\footnotetext{
${ }^{*}$ Corresponding Author :

E-mail addresses: sklin1105@yahoo.com.tw 1
} 
collaboration between the government and TFA. So-call East Asian model of PPP in agricultural modernization and rural community development may become a valuable experience for most of developing countries.

Keywords: Public-Private Partnership, Rural community development, Taiwanese Farmer Associations, Farmer cooperative organizations.

\section{Introduction}

This paper discusses a public-private partnership (PPP) formed by the government and Taiwanese Farmer Associations (hereafter TFA) ${ }^{\dagger}$. There are similar agricultural cooperative organizations in the East Asian region. The Japanese government imported the German cooperative society in the early 20 centuries. Later, Japan built similar farmer cooperative organizations in Korea and Taiwan for war-time economy. Actually, small-size farmers in the East Asian societies generally organize the cooperative organizations to get a better position in the market economy. Japan Agricultural Cooperatives (JA) are a kind of farmer organizations established under the Agricultural Cooperative Law which are involved in a comprehensive range of business, marketing, extensions, and insurance services, etc. under a mutual assistance within members and governmental policy support. JA have been making great contributions to the agricultural industry and the modernization of rural areas through their various business and social and economic activities.

Farmers Associations in Taiwan were basically developed from Japanese experiences of cooperative societies prior to World War II. As the Chinese government moved to Taiwan, it reformed those cooperative organizations for a economic, social, and political control. Nowadays, those farmer organizations have well developed in a good governance that play a significant policy agent in the rural development and agricultural modernization in Taiwan. This paper based on public-private partnership approach tries to examine a collaborative pattern between the government and TFA that has successfully promoted rural development and modernization since 1950s in Taiwan.

The government has supported and built TFA to be able to carry out public programs for the development of rural community and agricultural business. Their cooperative model not only reveals significant public-private partnership, but also indicates a remarkable civic engagement in public policy implementation. This is an interesting case for a third sector ${ }^{\ddagger}$ that involves in public service delivery.

\footnotetext{
$\dagger$ There are some similar farmer organizations in In East Asia. Although, there are different English translation, the formation, function, missions of organization are similar each other. Such as, Japanese Agricultural Cooperative Society(JA) in Japan, Agricultural Cooperatives (NonghHyup in Korean, NH) in South Korea, and Farmer Cooperative Society in China, Taiwan Farmer Associations (TFA) in Taiwan.

$¥$ In this paper, agricultural cooperative societies existing in East Asia societies are defined as a kind of third-sector organizations. According to Samiul Hasan, Mark Lyons, and Jenny Onyx, the Third 2
} 


\section{Agricultural Cooperative Organizations in East Asia}

TFAs as Korea and Japan have played a significant role in rural development since 1950s. Such an institutional arrangement largely improves the agricultural production, quality of life, and welfare in the rural communities. Many of these services, with the characteristics of "merit good" in that they are regarded as socially desirable, are usually provided by the governments. However, Taiwan, Korea, and Japan have similar experiences that agricultural cooperative organizations under government backing carry out public programs agricultural modernization.

Farmer cooperative organizations were primarily established in Japan during the early 20centry. Initially, these organizations were formed by volunteering in that farmers took collection to strengthen their bargaining power in market economy. Particularly, small farmers gather small amount of products into a large volume to get a bargaining power and reduce transaction cost in the market. Later, they were forced to transfer into government control. As a consequence, all farmers were obliged to join the organizations based on different prefectural governments to support the wartime economy (Nonaka 2006:1). During the Post World War II, almost all farm households joined the Japanese Agricultural Cooperative Societies (called JA) under a regulation of the Agricultural Cooperative Society Act promulgated in 1947. Each village had one farmer cooperative organization that provided all agricultural production-related services for farm households. At this time, the Japanese farmer cooperative organizations at prefectural and national levels run many businesses such as credit, insurance, purchasing, marketing and extension services. JA have performed great functions related to agricultural policies such as governmental loan, control of rice supply and price (Nonaka 2006: 3). JA provides guidance on various agricultural production services, including technologies, banking, marketing, and farm management, to individual members to help them operate their farms more efficiently.

Agriculture in Korea can be characterized with a small family farm structure. The average farm size was as small as 1.48 hectares in 2004. Following the promulgation of Agricultural Cooperative Law in 1957, Korean agricultural cooperative organizations (Nongh Hyup, $\mathrm{NH}$ in Korean), were established in 1958 to engage in the supply and marketing business of farmers. They consist of 2.4 million member farmers and about 1220 member cooperatives and one apex federation, the NACF. NHs in Korea were founded as three-tiered system with village-level, city-level and NACF at the national level.

Korean NHs as Japan and Taiwan, have experienced several stages of to profit their owners. Organizations that make up the third sector are the product of private collective action to provide goods or services for their members or for others (Hasan and Onyx 2008: 2). 
organizational transformation. In the 1960s, Korean NHs introduced mutual credit services that eliminated the practice of usury, notorious private high interest rate loans in rural areas. These organizations provide farmers capital for their farm enterprises. In the 1970s, they started cooperative chain store business which greatly contributed to stabilizing commodity prices in the country. In the 1980 s, they promoted farm mechanization programs and crop and breed improvement that largely upgraded farm productivity and increase farm household income. Those efforts cooperatives make have promoted agricultural modernization and rural community development. In the early 2000s, Korean NH played a leading role to implement the New Rural Community Campaign to revitalize the agricultural industry and rural community. NHs have also launched a campaign of 'Love Our Farming Villages' for making villages more vibrant places to live. NHs had made continuous institutional reform and innovation to overcome challenges from the liberalization of agricultural sector in Korea. Actually, farmer cooperative organizations in Japan, Korea, and Taiwan, with similar governance and close relations with governments, all plays an important part in agricultural modernization and development of rural community. The distinctive collaborations between the farmer organizations and governments in the rural development indicate a significant public-private partnership (PPP) in East Asia.

Table 1. Similarities and Differences of Agricultural Cooperative Organizations in East Asia

\begin{tabular}{|c|c|c|c|}
\hline & Japan & Korean & Taiwan \\
\hline No. of members & & 2.4 million & 1.8 million \\
\hline Dual membership & $\begin{array}{c}\text { member \& } \\
\text { associate member }\end{array}$ & $\begin{array}{c}\text { member \& } \\
\text { associate member }\end{array}$ & $\begin{array}{c}\text { member \& } \\
\text { associate member }\end{array}$ \\
\hline $\begin{array}{l}\text { No. of member } \\
\text { cooperatives }\end{array}$ & 550 & 1220 & 259 \\
\hline $\begin{array}{c}\text { Organization } \\
\text { Establishment based } \\
\text { on territory }\end{array}$ & $\begin{array}{c}\text { Three-tiers: } \\
\text { village-level } \\
\text { Prefecture-level } \\
\text { National level }\end{array}$ & $\begin{array}{l}\text { Two-tiers village-level } \\
\text { National level: NACF }\end{array}$ & $\begin{array}{c}\text { Three-tiers } \\
\text { village-level } \\
\text { county-level } \\
\text { Province- level }\end{array}$ \\
\hline Organization missions & $\begin{array}{c}\text { multi-function and } \\
\text { purpose: } \\
\text { 1.extension } \\
\text { 2.Marketting } \\
\text { 3.banking } \\
\text { 4. insurance }\end{array}$ & $\begin{array}{c}\text { multi-function and } \\
\text { purpose: } \\
\text { 1.extension } \\
\text { 2.Marketting } \\
\text { 3.banking } \\
\text { 4. insurance }\end{array}$ & $\begin{array}{c}\text { multi-function and } \\
\text { purpose: } \\
\text { 1.extension } \\
\text { 2.Marketting } \\
\text { 3.banking } \\
\text { 4. insurance }\end{array}$ \\
\hline Legal framework & $\begin{array}{c}\text { Agricultural } \\
\text { Cooperative Law }\end{array}$ & $\begin{array}{c}\text { Agricultural } \\
\text { Cooperative Law }\end{array}$ & $\begin{array}{c}\text { Farmer Association } \\
\text { Law }\end{array}$ \\
\hline $\begin{array}{c}\text { Government } \\
\text { Regulatory agency }\end{array}$ & Ministry of Agriculture & Ministry of Agriculture & $\begin{array}{c}\text { Commission of } \\
\text { Agriculture(cabinet } \\
\text { level) } \\
\end{array}$ \\
\hline President & member electing & & $\begin{array}{l}\text { Board of Director } \\
\text { electing }\end{array}$ \\
\hline & business tax exemption & & $\begin{array}{c}\text { Business tax } \\
\text { exemption }\end{array}$ \\
\hline Operation territory & on a restricted territory & on a restricted territory & on a restricted territory \\
\hline
\end{tabular}

\section{The Nature of Partnership and Newly Applied to Policy Issues}


Public-private partnership can be defined as an arrangement whereby private parties participate in, or provide support for, the provision of infrastructure. Conventionally, a PPP project results in a contract for a private entity to deliver public infrastructure-based services (Grimsey and Lewis 2004: 2). According to Grimsey and Lewis, a broader framework of PPP encompasses both "policy-level" partnership and "project-level" partnership. The former coordinates public sector and private sector inputs into decision-making about the design and formulation of policy initiatives. For example, urban transportation, subway system, or industrial development zone planning have been practiced in all world of many countries in past decades. No matter how PPP is defined, conventional PPP is almost constrained as infrastructure. They are largely applied to economic areas like highways, bridges, tunnels, and so on (Grimsey and Lewis 2004: 7). Particularly, it is always linked with Build Operate Transfer, BOT/ (Build Own Operate, BOO). Actually, there are many different types of PPPs and the models applied different from country to country. The PPP concept is evolving in different issues in which the arrangements and application are being implemented. In other words, PPP should go beyond conventional arrangement and application. It may be formed as an institutional arrangement that combines resources of public and private sectors and be used to deal with national and social development affairs. This paper tries to extend and use ideas of PPP in dealing with collaboration between the government and farmer organization in rural development process.

It seems the fact that Linder (1999: 35) defines PPP as a rubric for describing cooperative ventures between the state and private business. According to Linder, PPP should be more comprehensive and inclusive for widely applied in various new issues emerging since 2000s. The concept of PPP was usually limited to use in hardware-related public projects. Nevertheless, PPP should be extended to use in various policy issues, including agriculture, social welfare, the aged medicare, cultural and creative industrial policy etc. For most developing countries, governments have been the principal provider of infrastructure. Faced with effectiveness and efficiency in terms of financial input, construction projects implemented by governments have turned to the private sector. There have been so many successful projects that are implemented by specific PPP process and mold. However, few academic works discuss a particular type of institutional arrangement involving public agencies and civic organizations that may be able to co-work development of rural community.

\section{Governance of PPP in Rural Development in Taiwan}

Taiwan has faced small farming problem as Japan and Korea. Its average farm size was as small as 1.4 hectares per farmer during decades. As one of small farming societies in East Asia, farmers in Taiwan had organized their first cooperative organization in order to strengthen their bargaining power in market economy in 1899. 
Later, these organizations were forced to convert into government agency in early 1930s for Japanese government's food control. The Post World War II, they came through several stages of organizational transformation during the past decades. This paper focuses on Taiwanese experiences that suggest a distinctive public-private partnership between the government and farmer cooperative organizations in the issue of rural development. It is essentially characterized with institutional infrastructure that corresponds to what institutional economics calls the institutional environment (Williamson 1975). This partnership includes formal and informal institutional arrangement that shape economic behavior of private sector and decision-making process of the government (North, 1990; Williamson, 1985). It governs bureaucratic behavior, agriculture policies, public financing, along with formal regulation and informal government-business networks that institutionally transformed into a supportive force to promote rural development.

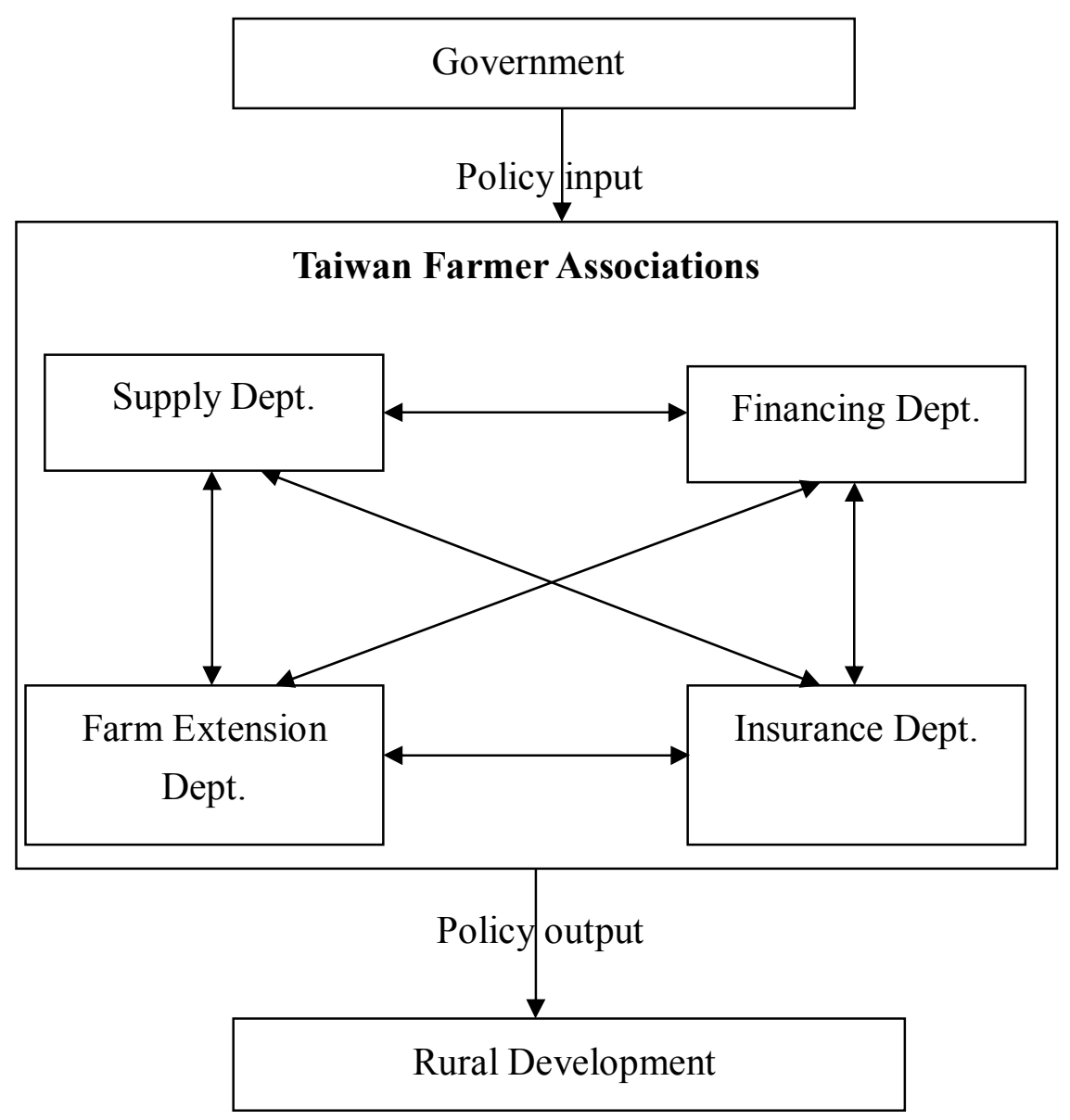

Figure 1 PPP Governance of Rural Development in Taiwan

Not all kinds of PPPs have been successful in all of societies. PPP built in the government and TFA shows a very noteworthy establishment in Taiwan. As Figure 1 shows, the government supports TFA administratively and politically. General manager election of TFA is legally regulated by Farmer Association Law and is 
politically controlled by the government. TFA has four policy-oriented functions, i.e. supply, farm extension, financing, and insurance that form four major departments to carry out their business and public programs commissioned by the government. It becomes a multi-function-goal in terms of service provision for farmer production and marketing. Its major roles can be concluded as the followings:

(i) It acts as a policy agent who helps the government to maintain a proper food policy and implement agricultural and social welfare programs.

(ii) It provides farmers with public goods such as information, technologies and resources sharing for production, and helps farmers to achieve agricultural modernization through provision of cultivating knowledge, collecting marketing, banking, and insurance.

(iii) It holds political power and retains political stability in rural areas in Taiwan.

As described previously, TFA, although it carries out some public policies commissioned by the government, is neither a governmental agency nor a business organization. However, it forms through farmers' voluntary action regulated by Farmer Associations Law and provides abundant economic, social, and educational public goods. TFA's multi-functions-and-goals are achieved through four departments, including transportation and marketing, education extension, banking, and insurance departments. Each department has its unique missions and goals, but they support each other under service-oriented guidance regulated by a legal framework and sponsored by the government.

As Figure 1 shows, TFA has four major departments to run four functions and carry out agriculture-related policy.

\section{(1) Economic Function:}

In general, the agricultural sector is weak in developing countries. Farmers in Taiwan averagely own small piece of land for farming. It is difficult to carry out modernized cultivation in such a small-farm structure. Apparently, production cost for small farms is high, and productivity is low. In this respect, TFA, as a client of the government takes a complementary part of the public- sector agencies to help farmers improve productivity through their cooperative apparatus. Since TFA is a civil organization, its cooperative device and governance have penetrated into local communities and established close and trustful relations with farmers and their families. Under administrative guidance of government, it provides all kinds of services, such as agricultural technological services, and supply handling and purchasing, selling commodities, rice grounding, which forms well organized service networks from living to production.

As Table 2 shows, TFA helps farmers to improve cultivation skills, teaches farmers how to use modernized farm tools, and how to properly use pesticides, and 
how to use new kinds of crop seeds to farmers from government-sponsored agricultural laboratory. Those technical assistances and services have effectively upgraded agricultural production capabilities in rural communities; consequently, it has raised income distribution of farm villages which is indispensable for rural modernization in Taiwan since the 1950s. As farmers use more modernized skills, tools, and seeds provided through FAT networks, the agricultural sector was highly grown. In addition, TFA also plays a role of local banking which provides loans for farmers. TFA as a farmers' cooperative organizations, also provides a warehousing business and product processing services for its small-farm members. Those production-related services substantially lower the cost of farming production, and upgrade productivity. For example, FAT provides warehousing services for rice, worth an average of 45 million NT dollars from 1991 to 2002, and 15 million NT dollars from 1995 to 2002 for frozen warehousing services.

Most significant is the financial services. TFA, with credit department, provides farmers with various agricultural loans that are crucial for agricultural production. There are three types of loans, including unified loans, project loans, and agricultural development loans. In short, TFA's economic functions are operated through agricultural extension, banking services, transportation and marketing, supply of tools, and insurance. Those services enhance the agricultural policy implementation of the government and essentially improve productivity of the agricultural sector in general. FAT has significantly acted as an economic policy agent and substantially fostered rural development, consequently retaining political stability in rural areas.

\section{(2) Social Function:}

Except economic-respect services for improvement of agricultural production capability, T FA also provides social-respect services in order to improve the quality of life in rural areas in Taiwan. Farmers in general are low-income and less educated classes. TFA under support of government provides various social services, such as family planning, financial management, recreations, and leadership training through its network system in order to lead them from underdeveloped into developed and modernized society. As Table 2 and Table4 shows, TFA provides kindergarten and nursery services which make women in rural communities to be able to join farm production, consequently increases production capacity to a large extent. In addition, TFA also provides farmers with second-skill training averagely up to 1,030 classes and 39,133 students in from 1991 to 2002. In addition, TFA also provides low-income farmer families with scholarships averagely amounting to 90 million NT dollars and benefiting 32,809 students from 1991 to 2002, which substantially upgrades literacy of poor families in rural areas. One of most valuable services is writing service provision which is greatly helpful for less-educated farmers. TFA offers average 
981,389 case services from 1991 to 2002 . Table 4 demonstrates that TFA provides home economic extension to farmers. It total expenses, including personnel and operation has up to 1,026 million New Taiwanese Dollar. Those social welfare services as effective as economic services are valuable for modernization in rural areas. Actually, the government should be responsible for provision of those social services via education, social welfare policies. However, political institutions are not so as responsive as NGOs in terms of service delivery efficiency.

TFA with social capital has extensive networks incorporated in bureaucracy and significantly plays a development policy agent. Since TFA has been working together with the government on co-production of agricultural sector, it has become a policy-patron of the government. Consequently, TFA also plays a crucial political stabilizer in rural areas. Ruling party and political elite could effectively control rural sector and implemented modernization projects through TFA networks. Stabilization is important for modernization process in most developing countries. Lack of political stability will substantially harm development efforts promoted by governments. Political relations between TFA and the government in Taiwan work as patron-client relations which the government protect the organizational interests and members of TFA politically support public policies and ruling legitimacy of KMT. It reveals political partnership which is considerably beneficial to rural development in Taiwan. Political stability in rural communities reinforced by TFA's economic and social service supply; consequently, it leads to effectiveness of development policy carried out by the government.

\section{(3) Educational Function:}

Table 3, and Table 5 indicate that TFA also helps the government to provide farm extension education services in rural areas. Social education programs which contain knowledge of food, clothing, housing, transportation, health and sanitation, and recreation are generally insufficient in farmer education. As growth of industrialization in Taiwan, large number of labors moves to urban. Consequently, human resources in rural areas become aged. As the social-economic environment has dramatically changed from traditional farming to commerce and industry, farmers must have sufficient knowledge of modern business management to low cost and raise productivity. TFA plays a role to help farmers upgrade their production and management skills. TFA teaches those aged and less education farmers to run farms with modern business management skill for improving production value. As Table 3 shows, TFA offers many farm extension education programs, including marketing 
class, 4-H extension ${ }^{\S}$, and home economic extension to farmers in order to promote rural modernization. Table 4 reveals that TFA provides home economic extension services averagely amounting to 118,847 thousand NT dollars from 1991 to 2017.

Table 2 Social Services in Rural Areas

Unit: classes, persons, NT thousand, cases

\begin{tabular}{|c|c|c|c|c|c|c|c|}
\hline \multirow{2}{*}{ Year } & \multicolumn{2}{|c|}{ Kindergarten } & \multicolumn{2}{|c|}{ Training Services } & \multicolumn{2}{c|}{ Scholarship } & Writing \\
& Classes & Children & Classes & Persons & Amounts & Persons & Cases \\
\hline 1991 & 1398 & 48186 & 626 & 21555 & 31086 & 22152 & 5788896 \\
\hline 1992 & 4277 & 46162 & 939 & 30584 & 39786 & 25492 & 3274978 \\
\hline 1993 & 989 & 32947 & 635 & 23048 & 181645 & 26963 & 297838 \\
\hline 1994 & 960 & 32318 & 757 & 37778 & 151123 & 28756 & 367402 \\
\hline 1995 & 937 & 31641 & 736 & 26263 & 159535 & 34120 & 369059 \\
\hline 1996 & 919 & 30647 & 905 & 38750 & 62670 & 35854 & 278956 \\
\hline 1997 & 849 & 28038 & 977 & 56215 & 61298 & 38586 & 306844 \\
\hline 1998 & 764 & 24364 & 1589 & 49378 & 154993 & 39447 & 223443 \\
\hline 1999 & 701 & 21703 & 1448 & 46659 & 67583 & 40352 & 201987 \\
\hline 2000 & 592 & 18880 & 1564 & 50570 & 67157 & 40872 & 236403 \\
\hline 2001 & 787 & 24352 & 783 & 44391 & 68443 & 35363 & 212586 \\
\hline 2002 & 728 & 20471 & 1395 & 44408 & 40416 & 25747 & 228280 \\
\hline 2003 & 472 & 13650 & 1239 & 35543 & 32598 & 19466 & 227752 \\
\hline 2004 & 453 & 12113 & 1686 & 47830 & 147840 & 33157 & 196446 \\
\hline 2005 & 477 & 13933 & 3839 & 79379 & 208636 & 40114 & 181922 \\
\hline 2006 & 354 & 8657 & 1349 & 36235 & 270943 & 60424 & 190497 \\
\hline 2007 & 485 & 11394 & 1215 & 34763 & 344909 & 63745 & 138085 \\
\hline 2008 & 522 & 11044 & 1117 & 30704 & 324376 & 57837 & 135074 \\
\hline 2009 & 381 & 7412 & 1485 & 38526 & 373772 & 64398 & 126168 \\
\hline 2010 & 389 & 7398 & 1214 & 38628 & 345919 & 63845 & 123245 \\
\hline 2011 & 376 & 7336 & 1317 & 40704 & 376914 & 69738 & 135074 \\
\hline 2012 & 381 & 7488 & 1485 & 48526 & 383772 & 74398 & 126168 \\
\hline 2013 & 378 & 7884 & 1332 & 42628 & 378823 & 68663 & 132464 \\
\hline 2014 & 392 & 8013 & 1314 & 40224 & 368842 & 67554 & 157553 \\
\hline 2015 & 394 & 8044 & 1217 & 34704 & 352114 & 57883 & 148996 \\
\hline 2016 & 388 & 8125 & 1385 & 42526 & 397789 & 69398 & 134221 \\
\hline 2017 & 386 & 7889 & 1314 & 40628 & 377864 & 67554 & 145667 \\
\hline Average & 745.51 & 18521.81 & 2490.14 & 40783.22 & 213725 & 47106.59 & 521703.90 \\
\hline & & 1 & & & & \\
\hline
\end{tabular}

Sources: Taiwan Farmers’ Associations Yearbook, 2010 ,2018

Table $3 \quad$ Farm Extension Services

Unit: classes, persons, NT thousand, cases

$\S 4-\mathrm{H}-\mathrm{Club}$ in the United States is a youth organization administered by the National Institute of Food and Agriculture of the United States Department of Agriculture (USDA), with the mission of "engaging youth to reach their fullest potential while advancing the field of youth development." The name represents four personal development areas of focus for the organization: head, heart, hands, and health. The organization has over 6.5 million members in the United States, from ages five to nineteen, in approximately 90,000 clubs. Clubs and related organizations now exist in many other countries as well; the organization and administration varies from country to country. FAT in Taiwan learned 4-H-Club from American rural development advisor, Dr. Anderson, and developed in Taiwan since the mid-1950s. 


\begin{tabular}{|c|c|c|c|c|c|}
\hline \multirow{2}{*}{ Year } & \multirow{2}{*}{$\begin{array}{l}\text { Villages } \\
\text { Involved }\end{array}$} & \multicolumn{2}{|c|}{ Production \& Marketing classes } & \multirow{2}{*}{ Demo Houses } & \multirow{2}{*}{$\begin{array}{c}\text { Operational } \\
\text { Expenses }\end{array}$} \\
\hline & & Classes & Students & & \\
\hline 1991 & 6303 & 25645 & 428458 & 12061 & 679648 \\
\hline 1992 & 6300 & 23620 & 467753 & 834837 & 739085 \\
\hline 1993 & 4878 & 14974 & 267921 & 9760 & 756519 \\
\hline 1994 & 4876 & 13597 & 263821 & 23965 & 834886 \\
\hline 1995 & 6047 & 16130 & 291414 & 11234 & 939542 \\
\hline 1996 & 12346 & 19817 & 373865 & 19344 & 1022951 \\
\hline 1997 & 12733 & 22453 & 424882 & 20955 & 1173313 \\
\hline 1998 & 6869 & 15275 & 301757 & 30920 & 906403 \\
\hline 1999 & 6586 & 14487 & 296092 & 18264 & 834350 \\
\hline 2000 & 6373 & 9855 & 202023 & 16693 & 735302 \\
\hline 2001 & 7057 & 23047 & 435720 & 22860 & 599705 \\
\hline 2002 & 5439 & 7063 & 154359 & 7223 & 378230 \\
\hline 2003 & 6909 & 7902 & 163056 & 5825 & 368217 \\
\hline 2004 & 7474 & 8570 & 170982 & 7172 & 361603 \\
\hline 2005 & 6694 & 7961 & 166166 & 5549 & 297431 \\
\hline 2006 & 6922 & 8739 & 177313 & 4953 & 339405 \\
\hline 2007 & 7038 & 8459 & 179053 & 5632 & 349057 \\
\hline 2008 & 6721 & 8027 & 172472 & 5713 & 365832 \\
\hline 2009 & 6693 & 7487 & 161774 & 5325 & 352360 \\
\hline 2010 & 6712 & 7894 & 163277 & 5343 & 355653 \\
\hline 2011 & 6694 & 7937 & 166166 & 5469 & 337431 \\
\hline 2012 & 6922 & 8235 & 173231 & 5121 & 389435 \\
\hline 2013 & 7027 & 8136 & 176753 & 5615 & 369127 \\
\hline 2014 & 6896 & 8027 & 183214 & 5707 & 365532 \\
\hline 2015 & 6893 & 7987 & 171788 & 5335 & 362360 \\
\hline 2016 & 6733 & 8422 & 188432 & 5321 & 358890 \\
\hline 2017 & 7012 & 8089 & 173668 & 5477 & 365667 \\
\hline average & 7005.44 & 12142.04 & 240570.70 & 41773.07 & 553256.80 \\
\hline
\end{tabular}

Sources: Taiwan Farmers' Associations Yearbook, 2010 ,2018

Table4 4-H-Extension

Unit: classes, persons, NT thousand, cases

\begin{tabular}{|c|c|c|c|c|c|}
\hline \multirow{2}{*}{ Year } & \multirow{2}{*}{$\begin{array}{l}\text { Villages } \\
\text { Involved }\end{array}$} & \multicolumn{2}{|c|}{ 4-H-Club } & \multirow{2}{*}{$\begin{array}{l}\text { Volunteer } \\
\text { Trainers }\end{array}$} & $\begin{array}{l}\text { Operational } \\
\text { Expenses }\end{array}$ \\
\cline { 3 - 5 } & & Teams & members & & 108403 \\
\hline 1991 & 206122 & 7761 & 136708 & 7505 & 113495 \\
\hline 1992 & 2283 & 7383 & 125060 & 7644 & 118813 \\
\hline 1993 & 4321 & 4594 & 79926 & 4928 & 128330 \\
\hline 1994 & 4754 & 4370 & 84488 & 5076 & 142255 \\
\hline 1995 & 5181 & 6170 & 108529 & 7634 & 148604 \\
\hline 1996 & 5181 & 10789 & 178872 & 11537 & 582306 \\
\hline 1997 & 5562 & 11086 & 179691 & 7090 & 758081 \\
\hline 1998 & 5652 & 5676 & 110515 & 7887 & 112784 \\
\hline 1999 & 5735 & 5283 & 97604 & 8159 & 109180 \\
\hline 2000 & 5733 & 4437 & 92127 & 11886 & 77182 \\
\hline 2001 & 6533 & 8578 & 173413 & 4450 & 54235 \\
\hline 2002 & 4466 & 3124 & 66642 & 5122 & 46034 \\
\hline 2003 & 5956 & 3479 & 76070 & 5421 & 41248 \\
\hline 2004 & 6383 & 3436 & 78935 & 5195 & 36530 \\
\hline 2005 & 5390 & 3232 & 77854 & 6153 & 44077 \\
\hline 2006 & 5504 & 3153 & 84101 & 6112 & 49384 \\
\hline 2007 & 5891 & 3455 & 85011 & 6344 & 50823 \\
\hline 2008 & 5495 & 2997 & 81700 & & \\
\hline
\end{tabular}




\begin{tabular}{|l|l|l|l|l|l|}
\hline 2009 & 5543 & 2795 & 73229 & 9240 & 51106 \\
\hline 2010 & 5455 & 2782 & 73211 & 6930 & 50122 \\
\hline 2011 & 5466 & 2733 & 72342 & 6450 & 54345 \\
\hline 2012 & 5658 & 2679 & 71970 & 6322 & 56034 \\
\hline 2013 & 6083 & 2678 & 71935 & 6425 & 55248 \\
\hline 2014 & 5998 & 2632 & 71854 & 6795 & 66530 \\
\hline 2015 & 5704 & 2653 & 71101 & 6753 & 54077 \\
\hline 2016 & 5891 & 2598 & 70011 & 6812 & 49213 \\
\hline 2017 & 5845 & 2517 & 69700 & 6844 & 50435 \\
\hline average & 1288.93 & 4558.15 & 94911.07 & 7109.26 & 118847.20 \\
\hline
\end{tabular}

Sources: Taiwan Farmers' Associations Yearbook, 2010 ,2018

Table 5 Home Economics Extension Unit: classes, persons, NT thousand, cases

\begin{tabular}{|c|c|c|c|c|c|}
\hline \multirow{2}{*}{ Year } & \multirow{2}{*}{ Villages Involved } & \multicolumn{2}{|c|}{ Training } & \multirow{2}{*}{ Volunteer Trainer } & \multirow{2}{*}{$\begin{array}{c}\text { Operational } \\
\text { Expenses }\end{array}$} \\
\hline & & Classes & members & & \\
\hline 1991 & 5653 & 12199 & 206025 & 11702 & 132584 \\
\hline 1992 & 6041 & 482829 & 205619 & 11685 & 164990 \\
\hline 1993 & 4648 & 7291 & 135479 & 7171 & 168486 \\
\hline 1994 & 4796 & 6976 & 135532 & 7593 & 189921 \\
\hline 1995 & 5812 & 10629 & 196326 & 11937 & 209904 \\
\hline 1996 & 5516 & 18045 & 333427 & 19645 & 228597 \\
\hline 1997 & 6853 & 155821 & 236064 & 22546 & 215505 \\
\hline 1998 & 6812 & 10162 & 217927 & 11669 & 215745 \\
\hline 1999 & 6942 & 9113 & 205938 & 9699 & 163993 \\
\hline 2000 & 6869 & 8439 & 192815 & 10104 & 181859 \\
\hline 2001 & 6784 & 15607 & 350150 & 21406 & 127647 \\
\hline 2002 & 5700 & 6205 & 146363 & 7280 & 102139 \\
\hline 2003 & 6668 & 7225 & 175756 & 15234 & 83793 \\
\hline 2004 & 7036 & 7619 & 186357 & 8457 & 87760 \\
\hline 2005 & 6379 & 7237 & 177978 & 8586 & 64528 \\
\hline 2006 & 6741 & 7638 & 191387 & 9502 & 75964 \\
\hline 2007 & 6876 & 7729 & 189343 & 10052 & 92854 \\
\hline 2008 & 6505 & 7391 & 188953 & 8888 & 91503 \\
\hline 2009 & 6657 & 7122 & 180110 & 9122 & 90319 \\
\hline 2010 & 6764 & 7211 & 182577 & 8975 & 90432 \\
\hline 2011 & 6668 & 7225 & 185756 & 9012 & 90793 \\
\hline 2012 & 7014 & 7345 & 186332 & 8857 & 90760 \\
\hline 2013 & 6979 & 7332 & 187978 & 9186 & 91528 \\
\hline 2014 & 6821 & 7556 & 191387 & 9523 & 89964 \\
\hline 2015 & 6889 & 7787 & 191343 & 10047 & 91877 \\
\hline 2016 & 7005 & 7791 & 189959 & 10058 & 91553 \\
\hline 2017 & 7057 & 7822 & 190110 & 10045 & 91456 \\
\hline average & 6462.41 & 31679.48 & 198407.10 & 11036.33 & 126535.30 \\
\hline
\end{tabular}

Sources: Taiwan Farmers' Associations Yearbook, 2010 ,2018

As Table 1-4 shows, TFA, actually playing a policy agent, offers farm extension services, 7306 villages involved and 341246 students benefited averagely from 1991 to 2017. It is clear that development policy function and its performance are operated through inclusive governance with social capital embedded on TFA. Regarding education services, most significant is $4-\mathrm{H}$ extension activities which designed and promoted for modernization education of youth groups in rural communities. 12 
According to Table 3, there are 6921 teams and 124,267 young men involving in 4-H programs averagely from 1991 to 2017. They show that the government financial and policy input are huge. Those programs and services, promoted by a particular collaboration between the government and TFA, have substantially benefited rural modernization in terms of human resources and farm production.

\section{Conclusion}

Rural development is really a complicate process. Development literature point out that underdevelopment in less developed countries results from a "governance crisis" characterized with bureaucratic obstruction, pervasive rent seeking, red tape, and corrupted politics in public institutions; as a result, it leads to the failure of public programs in general. Modernization theorists emphasize rational institutional arrangement and physical and human capital, including technical and financial elements which determine success of social modernization. This paper argues that inefficient governance or incapable public institutions are fundamentally caused by a lack of involvement of the third sector. Development action if carried out simply by the government which control over capital and technology may be failed as most developing countries have experienced in the past decades. This paper proposes that rural development and modernization of society should comprise public and private sectors all together as Taiwan, Korean, and Japanese experiences suggest. These two sectors may form a PPP governance which works on both resource input and policy implementation. In these circumstances, Taiwanese case indicates that successful PPP plays a role as a mediating variable that bridges public and private institutions and fosters development synergy. Taiwan Farmer Associations being a policy agent plays a supplementary role in giving an impetus to rural development in this island state. This shaping is an inherently political process that the state takes a leading role; nevertheless, the outcome is a combination of economic, social, and educational synergies.

TFA's participation in rural development programs not only strengthens their advocacy role but also represents farmers' policy participations in rural community development affairs through organizational cooperative delivery mechanism. Obviously, the Third Sector is becoming increasingly important in meeting social needs and in multiplying resources such as solidarity, trustworthiness, and cooperativeness which are intangible policy effectiveness. Partnership characterized with associative networks based on a unique partnership becomes mediating structures between civil society and the state, creates bonds of solidarity between the state and civil society, compensate function, and most significant, strengthens capability of governance.

Rural development process in Taiwan since 1950s reveals that civil society 
enhances societies' development by developing synergistic relationships with the public sector. The synergy has two components: complementary, referring to an extension to the capacity of government to achieve policy objectives, and partnership, referring to the successful cooperation between the government and farmer groups that enhance the effectiveness of development policies. The Third Sector substantially fill the social space left by the government, in terms of provision of social capital and social services. In other words, the farmer cooperative organizations in Taiwan are largely subsidiary to the state sector in terms of resources and policy enforcement. Investigation of rural modernization experiences in Taiwan may provide a theoretical contribution to linking between the practice of PPP and rural development. Through a thorough examination of the Taiwanese experiences, this paper proposes that an effective PPP has to be operated and practiced through a proper institutional arrangement. Particularly, effective institutional arrangement of PPP has to be supported by the government.

In East Asia, rural modernization has been successfully achieved under a appropriate PPP that regulates their interplays between the government and farmer organizations. Close cooperation between the governments and farmer cooperative organizations is crucial for their success. Significantly, farmer cooperative organizations have also benefited from conducting government programs. For small farmers particularly, it is crucial to get competitive advantage to make business successful in the marketplace (Choi 2006:15). It is a rationale for the government to deliver public services to grass root farmer households through farmer cooperative organizations with low transaction cost. Obviously, Korea, Japan, and Taiwan have analogous organizational governance, similar public-private cooperative practices, and outcome alike. So-call East Asian model of PPP in agricultural modernization and rural community development may become a valuable experience for most of developing countries.

\section{References}

Bacon, D. (2002) "Revitalizing Civil Society Through Social Capital Formation in Faith Based Organizations: Research Findings from Northern Ireland," prepared for Presentation at the fifth conference of the International Society for Third- Sector Research, July 7-11, 2002, Cape Town, South Africa.

Bifarello, M. "From Delegating to Participation: Third Sector and the State in Associative Networks," prepared for Presentation at the fifth Conference of the International Society for Third- Sector Research, July 7-11, 2002, Cape Town, South Africa.

Bonser, F. C. ed., (1995) Proceedings: The Role of NGOs in Economic Development 
"State-of-the-Art International Research Conference, International Institute of Administrative Sciences.

Chalmers, D. A., C. M. Vilas, K. Hite, S. B. Martin, K. Piester, and M. Segarra,Piester M. Segarra (eds.) (1997) The New Politics of Inequality in Latin America. Oxford: Oxford University Press.

Chambers, R. (1983) Rural Development: Putting the Last First. London: Longman. Choi, Jae-Hak, (2006), "Agricultural Cooperatives in Korea", 2006 FFTC-NACF International Seminar on Agricultural Cooperatives in Asia: Innovations and Opportunities in the 21st Century, Seoul, Korea, 11-15 September 2006.

Grimsey, Darrin and Mervyn K. Lewis, (2007), Public Private Partnership, Cheltenham, UK: Edward Elgar.

Hasan, Samiul and Jenny Onyx (eds.) (2008), Comparative Third Sector Governance in Asia: Structure, Process, and Political Economy, New York: Springer.

Nonaka, Akihisa, (2006) "The Agricultural Structure and Agricultural Co-ops in Japan”, 2006 FFTC-NACF International Seminar on Agricultural Cooperatives in Asia: Innovations and Opportunities in the $21^{\text {st }}$ Century, Seoul, Korea, 11-15 September 2006.

North, D. (1990) Institutions, Institutional Change and Economic Performance. New York: Cambridge University Press.

Rapley, J. ( 1996 ) Understanding Development: Theory and Practice in the Third World. Boulde, Co: Lynne Rienner Publisers.

Rashid, A. R. H. and A. Afandi, (1995) "NGOs and Development in Egypt: How Much do we know, and Where Do We Go from Here? In Bonser, Charles F. ed., Proceedings: The Role of NGOs in Economic Development "State-of-theArt International Research Conference, International Institute of Administrative Sciences: 23-28.

Regulska, J. (1999) "NGOs and their Vulnerabilities during the Time of Transition: The Case of Poland," Voluntas, (10)1: 61-71.

Taiwan Provincial Farmers Association, (2010) Farmers Associations Yearbook in Taiwan, 2010 edition.

Williamson, O. E. (1975). Market and Hierarchies. New York: Free Press. 